\title{
Nitrate leaching from Kentucky bluegrass soil columns predicted with anion exchange membranes
}

Salvatore S. Mangiafico

University of California - Riverside

Karl Guillard

University of Connecticut - Storrs, karl.guillard@uconn.edu

Follow this and additional works at: https://opencommons.uconn.edu/plsc_articles

Part of the Plant Sciences Commons

\section{Recommended Citation}

Mangiafico, Salvatore S. and Guillard, Karl, "Nitrate leaching from Kentucky bluegrass soil columns predicted with anion exchange membranes" (2007). Plant Science Articles. 24.

https://opencommons.uconn.edu/plsc_articles/24 


\section{Nitrate Leaching from Kentucky Bluegrass Soil Columns Predicted with Anion Exchange Membranes}

\author{
Salvatore S. Mangiafico \\ Dep. of Environmental Sciences \\ Univ. of California \\ Riverside, CA, 92521

\section{Karl Guillard*} \\ Dep. of Plant Science \\ Unit 4067 \\ Univ. of Connecticut \\ 1376 Storrs Rd. \\ Storrs, CT 06269-4067
}

\begin{abstract}
Ideal nitrogen $(\mathrm{N})$ management for turfgrass supplies sufficient $\mathrm{N}$ for high-quality turf without increasing $\mathrm{N}$ leaching losses. A greenhouse study was conducted during two 27-wk periods to determine if in situ anion exchange membranes (AEMs) could predict nitrate $\left(\mathrm{NO}_{3}-\mathrm{N}\right)$ leaching from a Kentucky bluegrass (Poa pratensis L.) turf grown on intact soil columns. Treatments consisted of 16 rates of $\mathrm{N}$ fertilization, from 0 to $98 \mathrm{~kg} \mathrm{~N}$ ha $^{-1} \mathrm{mo}^{-1}$. Percolate water was collected weekly and analyzed for $\mathrm{NO}_{3}-\mathrm{N}$. Mean flow-weighted $\mathrm{NO}_{3}-\mathrm{N}$ concentration and cumulative mass in percolate were exponentially related (pseudo- $R^{2}=0.995$ and 0.994 , respectively) to AEM desorbed soil $\mathrm{NO}_{3}-\mathrm{N}$, with a percolate concentration below $10 \mathrm{mg} \mathrm{NO}-\mathrm{N} \mathrm{L}^{-1}$ corresponding to an $\mathrm{AEM}$ soil $\mathrm{NO}_{3}-\mathrm{N}$ value of $2.9 \mu \mathrm{g} \mathrm{cm}^{-2} \mathrm{~d}^{-1}$. Apparent $\mathrm{N}$ recovery by turf ranged from 28 to $40 \%$ of applied $\mathrm{N}$, with a maximum corresponding to $4.7 \mu \mathrm{g} \mathrm{cm}^{-2} \mathrm{~d}^{-1} \mathrm{AEM}$ soil $\mathrm{NO}_{3}-\mathrm{N}$. Turf color, growth, and chlorophyll index increased with increasing $\mathrm{AEM}^{-}$soil $\mathrm{NO}_{3}-\mathrm{N}$, but these increases occurred at the expense of increases in $\mathrm{NO}_{3}-\mathrm{N}$ leaching losses. These results suggest that AEMs might serve as a tool for predicting $\mathrm{NO}_{3}-\mathrm{N}$ leaching losses from turf.
\end{abstract}

Abbreviations: AEM, anion exchange membrane; CIE, Commission Internationale de l' Eclairage; MCL, maximum contaminant level
$\mathrm{T}_{\mathrm{s}=\mathrm{e}}^{\mathrm{h}}$ There is concern about the negative impacts on surface and groundwater quality of $\mathrm{N}$ losses from turf areas. These concerns are becoming more acute with the expansion of urban and suburban areas that may be dominated by managed turf areas. No soil test for $\mathrm{N}$ is commonly used in humid climates to guide $\mathrm{N}$ applications to turfgrass. Instead, turfgrass is often fertilized according to a predetermined schedule or according to expected quality response of the turf. However, scheduled $\mathrm{N}$ fertilizer applications do not take into account plant available $\mathrm{N}$ added to the soil by mineralization or residual mineral $\mathrm{N}$ from previous applications. Because scheduled applications are not adjusted for existing available $\mathrm{N}$, applied $\mathrm{N}$ may be in excess of plant needs. Under common soil conditions, excess labile soil $\mathrm{N}$ may be converted to $\mathrm{NO}_{3}-\mathrm{N}$ and become subject to leaching. The goal of turfgrass $\mathrm{N}$ fertilization is to apply sufficient $\mathrm{N}$ to achieve high-quality turf without the accumulation of excess soil $\mathrm{N}$ that could lead to higher $\mathrm{N}$ leaching losses.

A decrease in apparent $\mathrm{N}$ recovery at higher $\mathrm{N}$ fertilizer application rates has been noted in cool-season mixed species turfs (Kopp and Guillard, 2002a; Fitzpatrick and Guillard, 2004) and in sandbased creeping bentgrass (Agrostis stolonifera L.) turfs (Huang and Petrovic, 1994). This effect has been noted also in orchardgrass (Dactylis glomerata L.), tall fescue (Festuca arundinacea Schreb.), and smooth bromegrass (Bromus inermis Lyess.) grass hay fields (Guillard et al., 1995a; Zemenchik and Albrecht, 2002; Hall et al., 2003; Singer and Moore, 2003). Furthermore, higher residual soil $\mathrm{NO}_{3}-\mathrm{N}$ resulting from higher $\mathrm{N}$ application rates has been noted in grass hay fields (Guillard et al., 1995b; Hall et al., 2003; Singer and Moore, 2003). Higher rates of $\mathrm{N}$ application coupled with lower $\mathrm{N}$ recovery,

Soil Sci. Soc. Am. J. 71:219-224

doi:10.2136/sssaj2005.0212

Received Received 2 July 2006.

*Corresponding author (karl.guillard@uconn.edu).

(c) Soil Science Society of America

677 S. Segoe Rd. Madison WI 53711 USA which result in higher concentrations of residual soil $\mathrm{NO}_{3}-\mathrm{N}$, suggest that $\mathrm{NO}_{3}-\mathrm{N}$ leaching is increased at high rates of $\mathrm{N}$ application. Increased $\mathrm{NO}_{3}-\mathrm{N}$ leaching from turf with higher rates of $\mathrm{N}$ application has been noted (Morton et al., 1988; Mancino and Troll, 1990; Huang and Petrovic, 1994; Kopp and Guillard, 2005; Frank et al., 2006). However, soil $\mathrm{NO}_{3}-\mathrm{N}$ available for leaching is decreased by microbial immobilization, plant uptake, and other losses and is augmented by mineralization of $\mathrm{N}$-bearing organic matter. A measurement of available soil $\mathrm{NO}_{3}-\mathrm{N}$ may serve as a better predictor of $\mathrm{NO}_{3}-\mathrm{N}$ leaching than would $\mathrm{N}$ application rate.

Anion exchange membranes (AEMs) have been used in situ to estimate available soil $\mathrm{N}$ in a variety of crops and soils (Pare et al., 1995; Qian and Schoenau, 1995; Wander et al., 1995; Ziadi et al., 1999; Koehn et al., 2002). Soil $\mathrm{NO}_{3}-\mathrm{N}$ desorbed from AEMs has been used as a predictor of perennial grassland yield (Collins and Allinson, 1999) and has been related to clipping yield, visual quality, and color in turfgrasses (Kopp and Guillard, 2002b; Mangiafico and Guillard, 2005; Mangiafico and Guillard, 2006b). In these studies, Cate-Nelson, linear plateau, and quadratic plateau models were used to indicate critical values of AEM-desorbed soil $\mathrm{NO}_{3}-\mathrm{N}$. There was a low probability of further turfgrass response to additional AEM-desorbed soil $\mathrm{NO}_{3}-\mathrm{N}$ above these critical values. The implication of these studies was that soil $\mathrm{NO}_{3}-\mathrm{N}$ added in excess of these critical $\mathrm{AEM}$ soil $\mathrm{NO}_{3}-\mathrm{N}$ values, if not taken up by plants or immobilized by microbes, might be subject to leaching losses. No study has attempted to correlate AEM-measured soil $\mathrm{NO}_{3}-\mathrm{N}$ with $\mathrm{NO}_{3}-\mathrm{N}$ leaching losses from turfgrass.

Objective color measurements of turf can be made with hand held reflectance meters. Commission Internationale de l' Eclairage (CIE) hue and lightness measurements from tristimulus chroma meters have been correlated with visual color assessments in bentgrass (Agrostis stolonifera L., A capillaries L.) (Landschoot and Mancino, 2000), with foliar $N$ concentration in creeping bentgrass (Landschoot and Mancino, 1997), and with chlorophyll concentration in clippings of Kentucky bluegrass and creeping red fescue 
(Festuca rubra L.) turf (Mangiafico and Guillard, 2005). An index of the chlorophyll content of a turf canopy can be estimated with the Spectrum CM1000 hand held reflectance meter (Spectrum Technologies, Inc. Plainfield, IL). This meter compares reflected red and infrared light to quantify chlorophyll content. Measurements from the CM1000 have been correlated to leaf chlorophyll concentration in a Kentucky bluegrass and creeping red fescue turf (Mangiafico and Guillard, 2005).

The purpose of this study was to determine if soil $\mathrm{NO}_{3}-\mathrm{N}$ desorbed from AEMs might serve as a predictor of $\mathrm{NO}_{3}-\mathrm{N}$ leaching from turfgrass.

\section{MATERIALS AND METHODS Experimental Design and Management}

A greenhouse study was conducted at the Plant Science Teaching and Research Farm at the University of Connecticut in Storrs, CT. Sixty-four intact soil columns were arranged in randomized complete block design and seeded to a Kentucky bluegrass blend (60\% 'Midnight', 20\% 'Apollo', 20\% 'Rambo' by weight) (LESCO, Inc., Strongsville, $\mathrm{OH}$ ). Treatments consisted of 16 rates of $\mathrm{N}$ fertilization: $0,4.9,9.8,14.7$ 19.6, 24.5, 29.3, 34.2, 39.1, $44.0,48.9,58.7,68.5,78.2,88.0$, and $97.8 \mathrm{~kg} \mathrm{~N} \mathrm{ha}^{-1} \mathrm{mo}^{-1}$ from May to October, 2003 and 2004, for a total of between 0 and $587 \mathrm{~kg} \mathrm{~N} \mathrm{ha}^{-1} \mathrm{yr}^{-1}$. Nitrogen was applied as aqueous $\mathrm{NH}_{4} \mathrm{NO}_{3}$.

Soil columns of an Agawam fine sandy loam (coarse-loamy over sandy or sandy-skeletal, mixed, active, mesic Typic Dystrudepts) were obtained in 1998 for use in an experiment concerning nitrate leaching from creeping bentgrass (Kopp and Guillard, 2005). Each column measured 76.2 $\mathrm{cm}$ tall by $20.3 \mathrm{~cm}$ inner diameter (i.d.). Schedule 40 PVC pipe was cut into sections, driven into the soil, and excavated to obtain undisturbed soil columns. In the greenhouse, each column was fitted with a high-density polyethylene funnel lined with glass fabric and pea stone to prevent soil loss. Each funnel was connected to a section of flexible PVC tubing $(2.54 \mathrm{~cm}$ i.d.) that drained percolate into a 1-L, low-density polyethylene collection vessel. At the beginning of our experiment, the top $10 \mathrm{~cm}$ of the mineral soil had a $\mathrm{pH}$ of 6.9, organic matter concentration of $29.1 \mathrm{~g} \mathrm{~kg}^{-1}$ (Ball, 1964), and $5.52 \mathrm{mg} \mathrm{kg}^{-1} 0.01 \mathrm{MCaCl}_{2}$ extractable $\mathrm{NO}_{3}-\mathrm{N}$ after initial fertilization at seeding.

In April 2003 and April 2004, columns were seeded with Kentucky bluegrass at a rate of $196 \mathrm{~kg}$ seed ha ${ }^{-1}$. Nitrogen as aqueous $\mathrm{NH}_{4} \mathrm{NO}_{3}$ was applied at seeding at a rate of $12.2 \mathrm{~kg} \mathrm{~N} \mathrm{ha}^{-1}$, and irrigation was then applied daily at a rate of $0.4 \mathrm{~cm} \mathrm{~d}^{-1}$ until the turf was established. Phosphorus as aqueous $\mathrm{KH}_{2} \mathrm{PO}_{4}$ and $\mathrm{K}$ as aqueous $\mathrm{KH}_{2} \mathrm{PO}_{4}$ and aqueous $\mathrm{KCl}$ were applied equally to all columns four times during the experiment according to soil test recommendations, for a total of $170 \mathrm{~kg} \mathrm{P} \mathrm{ha}^{-1}$ and $292 \mathrm{~kg} \mathrm{~K} \mathrm{ha}^{-1}$. Soil $\mathrm{pH}$ remained greater than 6.5 throughout the experiment without the addition of lime.

After turf establishment, irrigation was applied at $2.5 \mathrm{~cm} \mathrm{wk}^{-1}$ from May to November. Turf was grown in a greenhouse under natural light. A whitewash shading compound (Continental Products Co., Euclid, $\mathrm{OH}$ ) was applied to the greenhouse roof and walls each April and removed each October, resulting in a 38\% reduction in light intensity during this period. Automated controls in the greenhouse were set for a temperature range of 16 to $24^{\circ} \mathrm{C}$. Hydrogen dioxide (Biosafe Systems, Glastonbury, CT) was applied regularly throughout the experiment to turf leaves, and propiconazole \{1[[2-(2,4-dichlorophenyl)-4-propyl-1,3-dioxolan-2-yl]methyl]-1H1,2,4-triazole\} (Syngenta, Corp., Basel, Switzerland) was applied in May 2004, both for the control of powdery mildew (Erysiphe spp.). Imidacloprid \{1-[(6-chloro-3-pyridinyl)methyl]-N-nitro-2-imidazolidinimine\} (Olympic
Horticultural Products, Brandenton, FL) was applied in July 2004 to control fungus gnats (Bradysia spp.).

On 20 Nov. 2003 and 2004, the sod and the top $1.5 \mathrm{~cm}$ of soil was cut out from each soil column and discarded. This was done to prevent $\mathrm{N}$ uptake from the soil by the turf during the winter. In our climate, limited $\mathrm{N}$ uptake would occur under field conditions during this period. After turf removal, irrigation was applied to total $47.2 \mathrm{~cm}$, which is equal to the 30-yr normal precipitation total for Storrs, CT from 21 November to 31 March. This amount was intended to provide the total water input that would occur under normal field conditions for that period. This irrigation was applied in a single slow application at such a rate that there was no surface ponding. No further irrigation was applied until seeding the following spring. This was done to limit mineralization and immobilization of $\mathrm{N}$ in the soil columns during the winter.

\section{Percolate Collection and Anion Exchange Membranes}

Percolate volumes in the collection vessels were measured gravimetrically weekly from April to November, 2003 and 2004. Subsamples were stored at $4^{\circ} \mathrm{C}$ and analyzed within $48 \mathrm{~h}$ for $\mathrm{NO}_{3}-\mathrm{N}$ concentration on a Scientific Instruments continuous flow analyzer (WESTCO, Danbury, CT) using the Griess-Ilosvay method (Keeney and Nelson, 1982). When concentrations were below the nominal detection limit of $0.05 \mathrm{mg} \mathrm{L}^{-1}$, a value of half the detection limit was recorded. This was appropriate because the frequency of samples with concentrations below the detection limit was $2.8 \%$ of total samples (USEPA, 2000). Mass loss was calculated as the product of percolate $\mathrm{NO}_{3}-\mathrm{N}$ concentration and volume.

Sampling of available soil $\mathrm{NO}_{3}-\mathrm{N}$ with AEM strips (Ionics, Inc. Watertown, MA) was conducted every $2 \mathrm{wk}$ from May 2003 to October 2003 and from May 2004 to October 2004 for a total of 24 sampling dates. A large sheet of type-204 vinyl copolymer AEM fabric was cut into strips measuring $7.6 \mathrm{~cm}$ tall by $2.5 \mathrm{~cm}$ wide. Strips were prepared by shaking in $0.5 \mathrm{M} \mathrm{HCl}$ for $5 \mathrm{~min}$, rinsing in deionized water, saturating with $\mathrm{Cl}^{-}$ions by shaking for $2 \mathrm{~h}$ in $1 \mathrm{M} \mathrm{NaCl}$, and rinsing again in deionized water. Strips were stored in deionized water until use.

Anion exchange membrane strips were inserted into the soil by making a slit at an angle of approximately $15^{\circ}$ from vertical with a mason's trowel. An AEM strip was inserted so that the top of the AEM was at the soil surface. Hand pressure was used to close the slit and ensure soil contact with the AEM. A monofilament line and flagging tape were attached to each AEM to facilitate removal. After 2 wk, the strips were removed, and new strips were inserted. A new slit was made in a different location in the soil column each time a new AEM was inserted. Upon removal from columns, the AEMs were rinsed lightly with deionized water and placed individually in $60 \mathrm{~mL}$ HDPE bottles containing $25 \mathrm{~mL}$ of $1 M$ $\mathrm{NaCl}$. These bottles were transported immediately to the laboratory and shaken for $1 \mathrm{~h}$ to desorb $\mathrm{NO}_{3}-\mathrm{N}$ from the AEMs. The resultant extracts were filtered through papers having a retention range of 8 to $12 \mu \mathrm{m}$ (Schleicher and Schuell, Keene, NH). Extracts were stored at $4^{\circ} \mathrm{C}$ and analyzed within $48 \mathrm{~h}$ for $\mathrm{NO}_{3}-\mathrm{N}$. When concentrations were below the nominal detection limit of $0.05 \mathrm{mg} \mathrm{L}^{-1}$, a value of half the detection limit was recorded. The frequency of samples with concentrations below the detection limit was $1.2 \%$ of total samples.

\section{Turf Chlorophyll Index, Color, Yield, and Tissue Nitrogen}

Chlorophyll index measurements were taken with the Spectrum CM1000 reflectance meter on 24 dates during the experiment corresponding to the AEM sampling dates. Ten chlorophyll index measurements per 
column of the turf canopy were taken and averaged per column. All measurements were taken between $1000 \mathrm{~h}$ and $1400 \mathrm{~h}$ with the meter facing away from the sun. Measurements were taken holding the meter approximately $30 \mathrm{~cm}$ from the turf canopy, yielding a circular area of evaluation of approximately $1.3 \mathrm{~cm}^{2}$ per measurement. A Minolta CR 400 chroma meter (Konica Minolta Holding, Inc., Tokyo, Japan) was used to measure CIE hue and CIE lightness of the turf blades. For each measurement, fresh leaf blade clippings were laid flat into an optically dense stack. A color measurement was taken in CIE L* $a^{*} b^{*}$ coordinates at illuminant condition $C$. The leaf blades were then randomly rearranged in the stack, and another measurement was taken. This was repeated for five measurements for each column. Values of $\mathrm{L}^{*}, \mathrm{a}^{*}$, and $\mathrm{b}^{*}$ were averaged per column and converted to CIE hue and CIE lightness values (McGuire, 1992). Turf was clipped every $2 \mathrm{wk}$ to a height of $3.8 \mathrm{~cm}$. All clippings were collected, dried at $71^{\circ} \mathrm{C}$ for $48 \mathrm{~h}$, and weighed. Turf tissue was ground in a UDY Cyclone mill (UDY Corp., Ft. Collins, CO) to pass through a $0.5-\mathrm{mm}$ screen. Ground tissue samples were bulked for each column across all sample dates and analyzed for total $\mathrm{N}$ by persulfate digestion (Purcell and King, 1996) and subsequent $\mathrm{NO}_{3}-\mathrm{N}$ determination (Keeney and Nelson, 1982).

\section{Statistical Analysis}

Mean AEM soil $\mathrm{NO}_{3}-\mathrm{N}$ value across dates was plotted against $\mathrm{N}$ application rate, and a linear regression was developed. Mean flow-weighted percolate $\mathrm{NO}_{3}-\mathrm{N}$ concentration and cumulative mass across dates were calculated for each treatment. The fraction of applied $\mathrm{N}$ collected in percolate was calculated as the cumulative mass loss minus the cumulative mass loss for the $0 \mathrm{~N}$ treatment divided by the total amount of $\mathrm{N}$ applied. Mean flow-weighted percolate $\mathrm{NO}_{3}-\mathrm{N}$ concentration, cumulative mass loss, and fraction mass loss were plotted against mean AEM desorbed soil $\mathrm{NO}_{3}-\mathrm{N}$, and exponential $\left(y=a+b \mathrm{e}^{\mathrm{Cx}}\right)$ models were generated.

Cumulative $\mathrm{N}$ uptake was calculated for each treatment as the product of tissue $\mathrm{N}$ concentration and cumulative clipping yield across all sampling dates. Because tissue $\mathrm{N}$ concentration was determined on yieldweighted bulked samples, calculated $\mathrm{N}$ uptake was an unbiased estimate for actual $\mathrm{N}$ uptake. Apparent $\mathrm{N}$ recovery was calculated as the cumulative $\mathrm{N}$ uptake minus the cumulative $\mathrm{N}$ uptake for the $0 \mathrm{~N}$ treatment divided by total amount of $\mathrm{N}$ applied. Cumulative $\mathrm{N}$ uptake and apparent $\mathrm{N}$ recovery were each plotted against mean $\mathrm{AEM}$ soil $\mathrm{NO}_{3}-\mathrm{N}$, and a Gaussian curve model $\left\{y=a+b \mathrm{e}^{-0.5[c(x-d)]^{\wedge} 2}\right\}$ was developed for each. In the absence of any theoretical models, this model was chosen because it fit the data well and indicated $x$-axis values at which $y$-axis values were maximized.

Mean chlorophyll index, hue, lightness, and yield values across dates were plotted against mean soil $\mathrm{AEM} \mathrm{NO}_{3}-\mathrm{N}$ values, and a curvilinear Mitscherlich-Bray model $\left(y=a-b e^{-\mathrm{cx}}\right)$ was fit to each (Dahnke and Olson, 1990). Linear and curvilinear models were generated with the GLM or NLIN procedures in the Statistical Analysis Software package (SAS Institute, 1999) and were checked for homoscedasticity, normality of residuals, and independence of residuals (Tabachnick and Fidell, 2001).

\section{RESULTS AND DISCUSSION Application Rate and Anion Exchange Membrane Soil Nitrate}

Mean AEM-desorbed soil $\mathrm{NO}_{3}-\mathrm{N}$ was significantly $(p<$ 0.05 ) linearly related to $\mathrm{N}$ application rate (Fig. 1). This result corroborates results of previous studies that found significant relationships between AEM-desorbed soil $\mathrm{NO}_{3}-\mathrm{N}$ and $\mathrm{N}$ application rate (Collins and Allinson, 1999; Kopp and Guillard, 2002b; Mangiafico and Guillard, 2006b). The reciprocal of the slope of this regression line gives some indication of the amount of additional $\mathrm{N}$ fertilizer required to realize a marginal increase in AEM-desorbed soil $\mathrm{NO}_{3}-\mathrm{N}$, about $11 \mathrm{~kg} \mathrm{~N} \mathrm{ha}^{-1} \mathrm{mo}^{-1}$ for each $\mu \mathrm{g} \mathrm{cm}{ }^{-2} \mathrm{~d}^{-1}$ for the conditions of this experiment. However, because the data for this relationship are averaged across sample dates from two growing seasons and because the response of AEM-desorbed $\mathrm{NO}_{3}-\mathrm{N}$ to $\mathrm{N}$ application rate is affected by plant uptake, leaching losses, and microbial immobilization, this relationship may not hold on all sample dates or conditions.

\section{Percolate Nitrate Concentration and Mass}

Percolate was collected from at least some soil columns on 35 of 56 (63\%) sample dates. Dates when no percolate was collected tended to be in summer months, presumably when evapotranspiration exceeded irrigation rate. In results from field studies that present $\mathrm{NO}_{3}-\mathrm{N}$ leaching across time, periods in which no percolate was collected are evident (Guillard and Kopp, 2004; Mangiafico and Guillard, 2006a; Frank et al., 2006).

Significant exponential $(p<0.05)$ models were found relating percolate flow-weighted mean $\mathrm{NO}_{3}-\mathrm{N}$ concentration, cumulative $\mathrm{NO}_{3}-\mathrm{N}$ mass in percolate, and cumulative mass as fraction of $\mathrm{N}$ applied to AEM-desorbed soil $\mathrm{NO}_{3}-\mathrm{N}$ (Fig. 2). A mean percolate $\mathrm{NO}_{3}-\mathrm{N}$ concentration below the EPA maximum contaminant level (MCL) for drinking water of $10 \mathrm{mg} \mathrm{NO}_{3}-\mathrm{N} \mathrm{L}^{-1}$ was found for a mean $\mathrm{AEM}$ soil $\mathrm{NO}_{3}-\mathrm{N}$ value of $2.9 \mu \mathrm{g} \mathrm{cm}^{-2} \mathrm{~d}^{-1}$ (Fig. 2A). Similarly, based on the curvature of the model, Fig. 2B suggests moderate cumulative percolate $\mathrm{NO}_{3}-\mathrm{N}$ mass when AEM soil $\mathrm{NO}_{3}-\mathrm{N}$ values did not exceed about $3 \mu \mathrm{g} \mathrm{cm}^{-2} \mathrm{~d}^{-1}$. The fraction of applied $\mathrm{N}$ collected as $\mathrm{NO}_{3}-\mathrm{N}$ in the percolate generally increased as AEM soil $\mathrm{NO}_{3}-\mathrm{N}$ increased (Fig. 2C). As a percent of $\mathrm{N}$ applied, mass loss in percolate predicted by the exponential model ranged from about 7 to $28 \%$ across treatments (Fig. 2C). Because percolate $\mathrm{NO}_{3}-\mathrm{N}$ concentrations of environmental concern may be much lower than the USEPA MCL for drinking water (Pierzynski et al., 2000), target soil $\mathrm{NO}_{3}-\mathrm{N}$ values should probably be lower than those producing percolate concentrations close to the USEPA MCL.

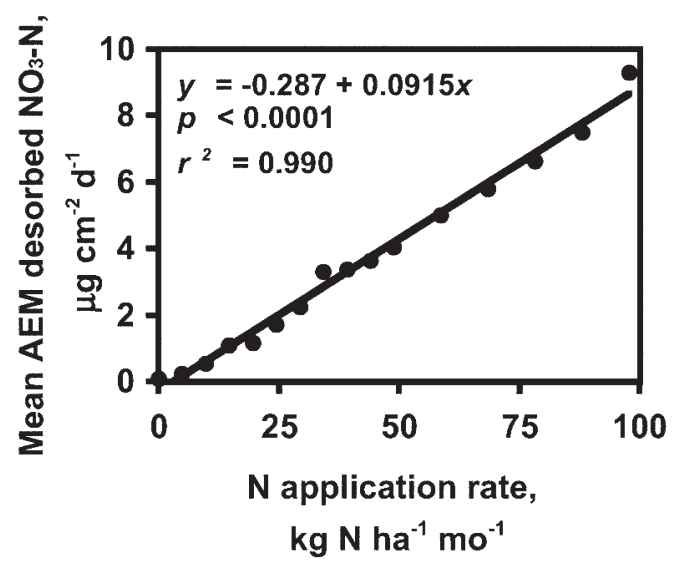

Fig. 1. Mean values of soil nitrate $\left(\mathrm{NO}_{3}-\mathrm{N}\right)$ desorbed from in situ anion exchange membranes (AEM) plotted against $\mathbf{N}$ application rate for Kentucky bluegrass (Poa pratensis L.) turf grown on a fine sandy loam soil. Soil $\mathrm{NO}_{3}-\mathrm{N}$ values were averaged by treatment from 24 dates across $2 \mathrm{yr}$. $\mathrm{N}$ was applied each month, May through October, 2003 and 2004, for a total of between 0 and $587 \mathrm{~kg} \mathrm{ha}^{-1} \mathrm{yr}^{-1}$. A fitted linear regression is shown. 
Considering $\mathrm{N}$ application rates, our percolate $\mathrm{NO}_{3}-\mathrm{N}$ concentrations are comparable to those presented by Frank et al. (2006) for a field study with an established Kentucky bluegrass turf. They reported flow-weighted concentrations of 4 and $21 \mathrm{mg} \mathrm{NO}-$ $\mathrm{N} \mathrm{L}^{-1}$ for 98 and $245 \mathrm{~kg} \mathrm{~N} \mathrm{ha}^{-1} \mathrm{yr}^{-1}$ applied, respectively. Our flow-weighted concentrations at similar rates were 6.7 and $11 \mathrm{mg}$ $\mathrm{NO}_{3}-\mathrm{N} \mathrm{L}^{-1}$, respectively. Also, our percolate concentration results are similar to those presented by Geron et al. (1993) for the first year after seeding of Kentucky bluegrass for a comparable $\mathrm{N}$ application rate. In general, though, our percolate $\mathrm{NO}_{3}-\mathrm{N}$ concentrations are notably higher than other field studies, which reported mean concentrations up to $4.6 \mathrm{mg} \mathrm{L}^{-1}$ for up to $244 \mathrm{~kg} \mathrm{~N} \mathrm{ha}^{-1} \mathrm{yr}^{-1}$ applied (Morton et al., 1988; Geron et al., 1993; Miltner et al., 1996; Guillard and Kopp, 2004; Mangiafico and Guillard, 2006a). Because our flow-weighted average for percolate $\mathrm{NO}_{3}-\mathrm{N}$ concentration was
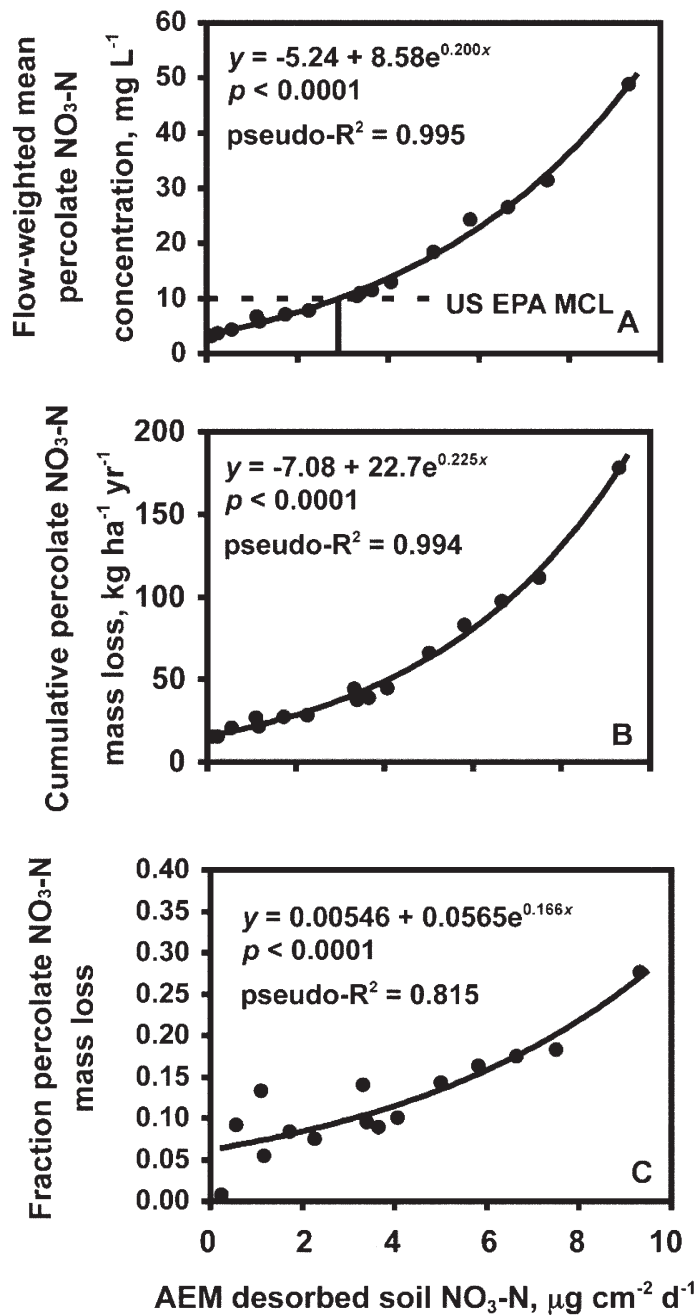

Fig. 2. Flow-weighted mean $\mathrm{NO}_{3}-\mathrm{N}$ concentration (A), cumulative nitrate $\left(\mathrm{NO}_{3}-\mathrm{N}\right)$ mass $(\mathrm{B})$, and cumulative mass as fraction of $\mathrm{N}$ applied (C) of percolate water from intact soil columns of fine sandy loam soil below Kentucky bluegrass (Poa pratensis L.) turf. Percolate data were collected on 54 dates across $2 \mathrm{yr}$ and are plotted in relation to mean soil $\mathrm{NO}_{3}-\mathrm{N}$ desorbed from in situ anion exchange membranes (AEM). A fitted exponential curve is shown for each plot. Dashed horizontal line represents the USEPA maximum contaminant level $(\mathrm{MCL})$ for drinking water of $\mathrm{NO}_{3}-\mathrm{N}$ of $10 \mathrm{mg} \mathrm{L}^{-1}$. Vertical line to the $x$-axis represents the soil $\mathrm{NO}_{3}-\mathrm{N}$ value corresponding to the MCL. greater than $3 \mathrm{mg} \mathrm{NO}_{3}-\mathrm{N} \mathrm{L}^{-1}$ for our $0 \mathrm{~N}$ application treatment, our percolate $\mathrm{NO}_{3}-\mathrm{N}$ concentration results may be elevated relative to some studies due to differences in $\mathrm{N}$ mineralization potential of the soil. If this is the case, it supports the argument that $\mathrm{NO}_{3}-\mathrm{N}$ leaching losses may be better predicted by some measurement of excess soil $\mathrm{NO}_{3}-\mathrm{N}$ than by $\mathrm{N}$ application rate alone. Fewer field studies reported mass losses for $\mathrm{NO}_{3}-\mathrm{N}$ in percolate, but our value of $28 \mathrm{~kg} \mathrm{~N} \mathrm{ha}^{-1} \mathrm{yr}^{-1}$ loss at $147 \mathrm{~kg} \mathrm{~N} \mathrm{ha}^{-1} \mathrm{yr}^{-1}$ applied is similar to reported values for comparable rates by field studies in our area (Guillard and Kopp, 2004; Mangiafico and Guillard, 2006a).

\section{Nitrogen Uptake, Recovery, and Use Efficiency}

Significant $(p<0.05)$ Gaussian curve models were found relating cumulative $\mathrm{N}$ uptake in clippings and apparent $\mathrm{N}$ recovery to mean AEM-desorbed soil $\mathrm{NO}_{3}-\mathrm{N}$ (Fig. 3). Cumulative $\mathrm{N}$ uptake increased with increasing $\mathrm{AEM}$ soil $\mathrm{NO}_{3}-\mathrm{N}$ to a modelpredicted maximum at $8.2 \mu \mathrm{g} \mathrm{cm}^{-2} \mathrm{~d}^{-1}$ of AEM soil $\mathrm{NO}_{3}-\mathrm{N}$ (Fig. 3A). This trend is in agreement with studies that found increasing $\mathrm{N}$ uptake with increasing rates of $\mathrm{N}$ application (Kopp and Guillard, 2002a; Fitzpatrick and Guillard, 2004). Apparent $\mathrm{N}$ recovery ranged from 28 to $40 \%$ of applied $\mathrm{N}$, with a maximum corresponding to $4.7 \mu \mathrm{g} \mathrm{cm}^{-2} \mathrm{~d}^{-1} \mathrm{AEM}$ soil $\mathrm{NO}_{3}-\mathrm{N}$ (Fig. $3 \mathrm{~B})$. This trend differs from studies that found monotonically decreasing apparent $\mathrm{N}$ recovery with increasing rates of $\mathrm{N}$ application (Kopp and Guillard, 2002a; Fitzpatrick and Guillard, 2004). These results suggest that increased leaching losses may be a result of less efficient recovery of $\mathrm{N}$ by turf when AEM soil
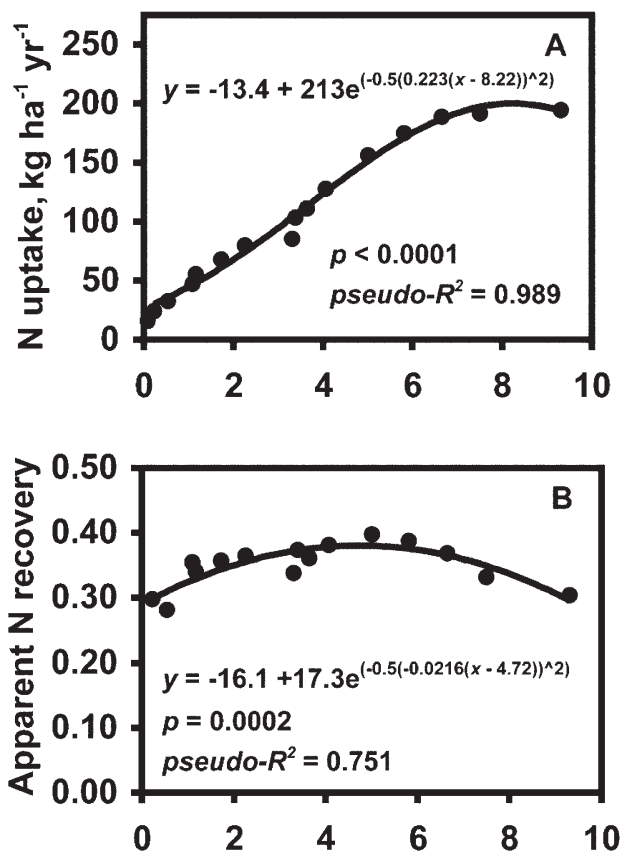

Mean AEM-desorbed soil $\mathrm{NO}_{3}-\mathrm{N}, \mu \mathrm{g} \mathrm{cm} \mathrm{cm}^{-2}$

Fig. 3. Cumulative $N$ uptake (A) and apparent $N$ recovery (B) of Kentucky bluegrass (Poa pratensis L.) turf in relation to soil nitrate $\left(\mathrm{NO}_{3}-\mathrm{N}\right)$ desorbed from in situ anion exchange membranes (AEM). The turf was grown on a fine sandy loam soil in greenhouse conditions. A fitted Gaussian curve is shown for each plot. Data for AEM soil $\mathrm{NO}_{3}-\mathrm{N}$ are averaged from 24 dates across 2 yr. Data for $N$ uptake and recovery are from leaf tissue samples bulked from 24 dates across two growing seasons. 
$\mathrm{NO}_{3}-\mathrm{N}$ was above $4.7 \mu \mathrm{g} \mathrm{cm} \mathrm{cm}^{-2}$. Below this value, however, increased leaching losses occurred with increasing AEM soil $\mathrm{NO}_{3}-\mathrm{N}$ leaching in spite of more efficient recovery. Values for cumulative $\mathrm{N}$ uptake and apparent $\mathrm{N}$ recovery included $\mathrm{N}$ collected only from clippings and do not include $\mathrm{N}$ in roots, rhizomes, or verdure.

\section{Turf Chlorophyll Index, Color, and Yield}

Significant $(p<0.05)$ Mitscherlich-Bray models were found relating mean chlorophyll index, hue, lightness, and yield measurements to mean AEM-desorbed soil $\mathrm{NO}_{3}-\mathrm{N}$ (Fig. 4). A higher $\mathrm{CM} 1000$ index implies a higher leaf chlorophyll concentration. A higher CIE hue in this range implies a greener leaf color. A lower CIE lightness implies a darker leaf color. Marginal changes in these variables with increases in AEM soil $\mathrm{NO}_{3}-\mathrm{N}$ were greatest at low AEM soil $\mathrm{NO}_{3}-\mathrm{N}$ values. However, these variables continued to change with increasing $\mathrm{AEM}$ soil $\mathrm{NO}_{3}-\mathrm{N}$ at high $\mathrm{AEM}$ soil $\mathrm{NO}_{3}-\mathrm{N}$ values. Color (Fig. $4 \mathrm{C}$ and 4D) and chlorophyll (Fig. 4A) development for our turf stand occurred at the expense of increases in $\mathrm{NO}_{3}-\mathrm{N}$ leaching losses (Fig. 2).

This effect was especially pronounced at high AEM soil $\mathrm{NO}_{3}-\mathrm{N}$ values when incremental additions of soil $\mathrm{NO}_{3}-\mathrm{N}$ increased turf color and chlorophyll only slightly but increased $\mathrm{NO}_{3}-\mathrm{N}$ leaching losses exponentially. Considering this, water quality concerns would dictate that turf $\mathrm{N}$ application should be managed to achieve acceptable quality for intended turf use and conditions but not to attempt to maximize turf color response.

\section{CONCLUSIONS}

Soil $\mathrm{NO}_{3}-\mathrm{N}$ desorbed from in situ AEMs was found to be a predictor for cumulative $\mathrm{NO}_{3}-\mathrm{N}$ mass and flow-weighted $\mathrm{NO}_{3}-\mathrm{N}$ concentration in percolate water collected from intact soil columns. Because percolate $\mathrm{NO}_{3}-\mathrm{N}$ flow-weighted concentration and cumulative mass were exponentially related to AEM soil $\mathrm{NO}_{3}-\mathrm{N}$, water quality concerns dictate minimizing excess soil $\mathrm{NO}_{3}-\mathrm{N}$ when possible. Increases in $\mathrm{NO}_{3}-\mathrm{N}$ leaching losses occurred with increases in AEM-desorbed soil $\mathrm{NO}_{3}-\mathrm{N}$ despite increases $\mathrm{N}$ uptake by turf. Turfgrass color, chlorophyll index, and growth increased with increasing $\mathrm{AEM}$ soil $\mathrm{NO}_{3}-\mathrm{N}$. These increases, however, were achieved at the expense of increases in $\mathrm{NO}_{3}-\mathrm{N}$ leaching. These results caution against managing nitrogen applications to achieve color development beyond the requirements of the intended use of a specific turf stand. Our results suggest that $\mathrm{AEMs}$ might serve as a tool for predicting $\mathrm{NO}_{3}-\mathrm{N}$ leaching losses from turfgrass.

Factors influencing $\mathrm{NO}_{3}-\mathrm{N}$ leaching from turfgrass include soil type, irrigation, $\mathrm{N}$ source, $\mathrm{N}$ rates, and $\mathrm{N}$ application timing (Petrovic, 1990). Although AEMs may capture soil $\mathrm{NO}_{3}-\mathrm{N}$ available for uptake or leaching, it is unclear how factors such as soil type or irrigation rate affect the relationship between $\mathrm{NO}_{3}-\mathrm{N}$ leaching and measured $\mathrm{AEM}$ soil $\mathrm{NO}_{3}-\mathrm{N}$. Because soil $\mathrm{NO}_{3}-\mathrm{N}$
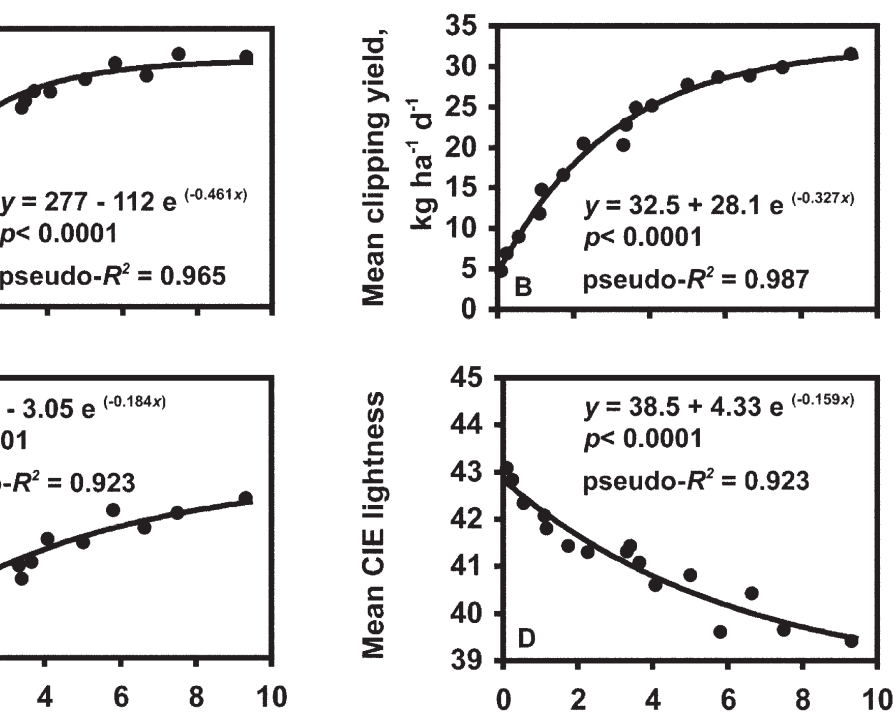

Mean AEM desorbed soil $\mathrm{NO}_{3}-\mathrm{N}, \mu \mathrm{g} \mathrm{cm} \mathrm{cm}^{-2} \mathrm{~d}^{-1}$ implies a higher canopy chlorophyll content. A higher CIE hue in this range implies a greener leaf color. A lower CIE lightness implies a darker leaf color.

is delivered to AEMs by mass flow and diffusion, low soil moisture contents may cause AEMs to underpredict the amount of soil $\mathrm{NO}_{3}-\mathrm{N}$ subject to leaching. Likewise, a continual wetting front at the depth of the AEM may deliver soil $\mathrm{NO}_{3}-\mathrm{N}$ to the AEM at a high rate, even if the nitrate leaching of that soil is relatively low.

Results of this study are limited by its greenhouse experimental conditions. For example, Geron et al. (1993) found seasonal effects on $\mathrm{NO}_{3}-\mathrm{N}$ leaching from Kentucky bluegrass turf to be greater than effects of fertilizer program or $\mathrm{N}$ source; our greenhouse study could not accurately mimic seasonal changes. The ability of AEMs to predict soil $\mathrm{NO}_{3}-\mathrm{N}$ leaching should be examined under field conditions to assess the robustness of the technique to variations in soil moisture and precipitation events and under a variety of climates, turf species, and soil types.

\section{ACKNOWLEDGMENTS}

Funding for this research was supplied by the USDA Hatch Funds Act program, Northeastern Regional Association of State Agricultural Experiment Station Directors project NE-187 "Best Management Practices for Turf Systems in the East," and the Connecticut Institute of Water Resources. We are grateful to Drs. Thomas F. Morris and John C. Clausen for their comments and suggestions for this paper.

\section{REFERENCES}

Ball, D.F. 1964. Loss-on-ignition as an estimate of organic matter and organic carbon in non-calcareous soils. J. Soil Sci. 15:84-92.

Collins, S.A., and D.W. Allinson. 1999. Use of anion exchange membranes to assess nitrogen needs of perennial grasslands. Commun. Soil Sci. Plant Anal. 30:2267-2282.

Dahnke, W.C., and R.A. Olson. 1990. Soil test correlation, calibration, and recommendation. p. 45-71. In R.L. Westerman (ed.) Soil Testing and Plant Analysis. 3rd ed. SSSA, Madison, WI.

Fitzpatrick, J.M., and K. Guillard. 2004. Kentucky bluegrass response to potassium and nitrogen fertilization. Crop Sci. 44:1721-1728. 
Frank, K.W., K.M. O'Reilly, J.R. Crum, and R.N. Calhoun. 2006. The fate of nitrogen applied to a mature Kentucky bluegrass turf. Crop Sci. 46:209-215.

Geron, C.A., T.K. Danneberger, S.J. Traina, T.J. Logan, and J.R. Street. 1993. The effects of establishment methods and fertilization practices on a nitrate leaching from turfgrass. J. Environ. Qual. 22:119-125.

Guillard, K., G.F. Griffin, D.W. Allinson, M.M. Rafey, W.R. Yamartino, and S.W. Pietrzyk. 1995a. Nitrogen utilization of selected cropping systems in the U.S. Northeast: I. dry matter yield, N uptake, Apparent N recovery, and $\mathrm{N}$ use efficiency. Agron. J. 87:193-199.

Guillard, K., G.F. Griffin, D.W. Allinson, M.M. Rafey, W.R. Yamartino, and S.W. Pietrzyk. 1995b. Nitrogen utilization of selected cropping systems in the U.S. Northeast: II. Soil profile nitrate distribution and accumulation. Agron. J. 87:199-207.

Guillard, K., and K.L. Kopp. 2004. Nitrogen fertilizer form and associated nitrate leaching from cool-season lawn turf. J. Environ. Qual. 33:18221827.

Huang, Z.T., and A.M. Petrovic. 1994. Clinoptilolite zeolite influence on nitrate leaching and nitrogen use efficiency in simulated sand based golf greens. J. Environ. Qual. 23:1190-1194.

Hall, M.H., D.B. Beegle, R.S. Bowersox, and R.C. Stout. 2003. Optimum nitrogen fertilization of cool-season grasses in the northeast USA. Agron. J. 95:1023-1027.

Keeney, D.R., and D.W. Nelson. 1982. Nitrogen-inorganic forms. p. 643-698. In A.L. Page (ed.) Methods of Soil Analysis, 2nd ed., Part 2, Chemical and Microbiological Properties. ASA, SSSA, Madison, WI.

Koehn, A.C., F.J. Peryea, D. Neilsen, and E.J. Hogue. 2002. Temporal changes in nitrate status of orchard soils with varying management practices. Commun. Soil Sci. Plant Anal. 33:3621-3634.

Kopp, K.L., and K. Guillard. 2002a. Clipping management and nitrogen fertilization of turfgrasses: Growth, nitrogen utilization, and quality. Crop Sci. 42:1225-1231.

Kopp, K.L., and K. Guillard. 2002b. Relationship of turfgrass growth and quality to soil nitrate desorbed from anion exchange membranes. Crop Sci. 42:1232-1240.

Kopp, K.L., and K. Guillard. 2005. Clipping contributions to nitrate leaching from creeping bentgrass under varying irrigation and $\mathrm{N}$ rates. Int. Turfgrass Soc. Res. J. 10:80-85.

Landschoot, P.J., and C.F. Mancino. 1997. Assessment of the Minolta CR-310 chroma meter for predicting nitrogen status of Agrostis stolonifera L. Int. Turfgrass Soc. Res. J. 8:711-718.

Landschoot, P.J., and C.F. Mancino. 2000. A comparison of visual vs. instrumental measurement of color differences in bentgrass turf. HortScience 35:914-916.

Mancino, C.F., and J. Troll. 1990. Nitrate and ammonium leaching losses from $\mathrm{N}$ fertilizers applied to 'Penncross' creeping bentgrass. HortScience 25:194-196.
Mangiafico, S.S., and K. Guillard. 2005. Turfgrass reflectance measurements, chlorophyll, and soil nitrate desorbed from anion exchange membranes. Crop Sci. 45:259-265.

Mangiafico, S.S., and K. Guillard. 2006a. Fall fertilization timing effects on nitrate leaching and turfgrass color and growth. J. Environ. Qual. 35:163-171.

Mangiafico, S.S., and K. Guillard. 2006b. Anion exchange membrane soil nitrate predicts turfgrass color and yield. Crop Sci. 46:569-577.

McGuire, R.G. 1992. Reporting of objective color measurements. HortScience 27:1254-1255.

Miltner, E.D., B.E. Branham, E.A. Paul, and P.E. Rieke. 1996. Leaching and mass balance of ${ }^{15} \mathrm{~N}$-labeled urea applied to a Kentucky bluegrass turf. Crop Sci. 36:1427-1433.

Morton, T.G., A.J. Gold, and W.M. Sullivan. 1988. Influence of overwatering and fertilization on nitrogen losses from home lawns. J. Environ. Qual. 17:124-130.

Pare, T., E.G. Gregorich, and B.H. Elliot. 1995. Comparison of soil nitrate extracted by potassium chloride and adsorbed on an anion exchange membrane in situ. Commun. Soil Sci. Plant Anal. 26:883-898.

Petrovic, A.M. 1990. The fate of nitrogenous fertilizers applied to turfgrass. J. Environ. Qual. 19:1-14.

Pierzynski, G.M., J.T. Sims, and G.F. Vance. 2000. Soils and Environmental Quality, 2nd ed. CRC Press, Boca Raton, FL.

Purcell, L.C., and C.A. King. 1996. Total nitrogen determination in plant material by persulfate digestion. Agron. J. 88:111-113.

Qian, P., and J.J. Schoenau. 1995. Assessing nitrogen mineralization from soil organic matter using anion exchange membranes. Fert. Res. 40:143148.

SAS Institute. 1999. SAS OnlineDoc, version 8. Cary, NC. Available at http://v8doc.sas.com (accessed 17 Jan 2005; verified 9 Oct. 2006).

Singer, J.W., and K.J. Moore. 2003. Nitrogen removal by orchardgrass and smooth bromegrass and residual soil nitrate. Crop Sci. 43:1420-1426.

Tabachnick, B.G., and S.F. Fidell. 2001. Using Multivariate Statistics, 4th ed. Allyn and Bacon, Boston, MA.

USEPA. 2000. Guidance for data quality assessment: Practical methods for data analysis. EPA QA/G-9 QA 00 update. EPA/600/R-96/084. USEPA, Washington, DC.

Wander, M.M., D.V. McCracken, L.M. Shuman, J.W. Johnson, and J.E. Box. 1995. Anion-exchange membranes used to assess management impacts on soil nitrate. Commun. Soil Sci. Plant Anal. 26:2383-2390.

Zemenchik, R.A., and K.A. Albrecht. 2002. Nitrogen use efficiency and apparent nitrogen recovery of Kentucky bluegrass, smooth bromegrass, and orchardgrass. Agron. J. 94:421-428.

Ziadi, N., R.R. Simard, G. Allard, and J. Lafond. 1999. Field evaluation of anion exchange membranes as a $\mathrm{N}$ soil testing method for grasslands. Can. J. Soil Sci. 79:281-294. 